\title{
SOME REMARKS ON THE TAXONOMY OF GYANOPHYGEAE
}

\author{
JOSÉPHINE TH. KOSTER \\ (Rijksherbarium, Leiden)
}

(received October 6th, 1965)

\begin{abstract}
Together with the class of the Schizomycetes (bacteria) the Cyanophyceae belong to the division of the Schizophyta which division differs from all other plant divisions by lacking a nucleus. However, the central part of their cells is a nuclear equivalent (Procaryota). This nucleoplasm or centroplasm or central body in the Cyanophycean cell has been studied profoundly these last fifteen years (Beck, Bowen, Cassel, Fuhs, Giesy, Herbst, Hutchinson, Jensen, Jost, Pankratz, Rabinovich, Sun and others) by means of the electron microscope. The resulting papers are mostly beautifully illustrated by electron micrographs. Pure cultures of Chroococcales (Gloeocapsa, Gloeothece, Pleurocapsa) as well as Hormogonales (Anabaena, Nostoc, Microcoleus, Oscillatoria, Phormidium, Symploca) have served for these investigations. The general results of these studies have provided us with a detailed picture of the nucleoplasm. The uncoloured nucleoplasm often has a fine reticulate-fibrillar texture, the anastomosing fibrils are intertwined by cytoplasm. In the nucleoplasm have been found to occur: vacuoles, opaque globular granules and polygonous bodies, which have a connection with the reticulate structure. Though the nucleoplasm contains nuclear material, the general conclusion is that there are no chromosomes and that no mitosis occurs. Only FuHs (1958), who discovered Feulgen-positive linear filiform or bar-shaped structures in the centroplasm, about $0.2 \mu$ in diameter, compared these with chromosomes, for their length is more or less constant and they split longitudinally into two diverging parts. He did not see any spindle-shape, however, inherent to mitosis. Cassel and Hutchinson (1954) doubt the possibility of a comparison with chromosomes since the resembling structures vary in shape and size in various cells.

Several former investigators were positive about the existence of a true nucleus and chromosomes in the cell of Cyanophyceae. KOHL (1903) wrote a book about: "Organisation und Physiologie der Cyanophyceenzelle und die mitotische Teilung ihres Kernes", in which numerous coloured figures show the mitosis and the chromosomes, observed with a light microscope. Tolypothrix lanata was used for these studies. Kohl did not see a nuclear membrane. To-day, investigators who have made electron-microscopic studies are convinced that no such a membrane between nucleoplasm and chromoplasm exists. They, however, do not at all confirm those bold conclusions concerning chromosomes and mitosis. Cell-division starts with an annular constriction of the protoplast.
\end{abstract}


The wall of the Cyanophycean cell consists of two, three or four layers. In the Hormogonales are found to occur fine connections through the cell-wall between the protoplast of two neighbouring cells. Inside the cell-wall is the coloured part of the cytoplasm, the chromo- or chromatoplasm, having lamellar structures to which chlorophyll and photo-synthesis are inherent. Also vacuoles and cyanophycine-granules occur in the chromoplasm.

The Cyanophyceae differ from the bacteria according to ForT, 1950 (pp. 27, 40) by never having moving flagellate cells and often having hormogonal, but never simple trichomes and by in many cases showing hormogonal movements. Consequently, like others, this author considers Beggiatoa and Thiothrix to belong to the Cyanophyceae, for these organisms have hormogonal trichomes and Beggiatoa shows Oscillatoria-like movements, Thiothrix forms hormogones. In Fott's opinion, the lack of photosynthetic pigments in such apochlorotic genera, as are Beggiatoa and Thiothrix, is an unreliable character, since many Cyanophyceae are only faintly coloured or nearly colourless and bacteria can be green or purple coloured. Soriano and LEWIN (1965) are of an opposite opinion. They deem the occurrence of the sulphur granules in the Beggiatoa cells, though rarely lacking, to be an important character and do not think it appropriate to place that genus in the Oscillatoriaceae nor in the Beggiatoaceae in the Hormogonales. They consider Beggiatoa to belong to the Flexibacteria. These authors indicate that there are numerous one- or more-celled apochlorotic gliding organisms without flagella, related to the Cyanophyceae but having no photosynthetic pigments, living in marine as well in freshwater habitats. Many of these organisms have been described originally as Oscillatoria species. There are gradual transitions from the above mentioned organisms to Myxobacteria. Soriano and Lewin conclude that there is no natural limit between the Cyanophyceae and the bacteria. Physiologally, as they indicate, there is some difference, since the Cyanophyceae possess chlorophyll a and evolve oxygen, whereas the bacteria generally are not photosynthetic and if so, do not evolve oxygen. After considering the above mentioned arguments, we may agree that no natural limit exists between the Cyanophyceae and the bacteria. In a recent paper Echirs and MORRIs (1965), after thorough considerations, came to the suggestion that "bacteria and blue-green algae should be isolated in a group distinct from all other organisms."

Despite the sharp delimitation of the Cyanophyceae from the other classes of algae, they are readily, also in the latest works on classification (Fotr, 1959; Christensen, 1964) placed among the Algae. In fact, the shape of the cells and of the colonies of several Cyanophycean species show a great resemblance to those of 'Chlorophycean species. Difficulties are met with in delimitation of the genera and the species of the Cyanophyceae. The morphological variability, as well as the differences caused by various environmental conditions and the different stages in growth, all suggest different species thus causing these difficulties. For this reason it is advisable, not to describe a new Cyanophycean species just because the material concerned is not 
identical with the species to which certain keys for identification lead or with descriptions in flora's, however good these may be. Finding in PANkow and Jahnke (1965, p. 332): "Oscillatoria lutescens nova spec. Eine am 27 Oktober 1963 aus einem Dorfteich in Dummerstorf (bei Rostock) entnommene Wasserprobe enthielt reichlich farblosgelblichgrüne Trichome einer Oscillatoria-Art, die sich mit Hilfe der gebräuchliche Bestimmungsschlüssel (Geitler, 1932; Desikachary, 1959) nicht bestimmen liess", or in WeLSH (1964, p. 258) concerning Oscillatoria Chutteri n. sp. "It will be seen from this diagnosis and the iconographs that this alga has certain features reminiscent of Oscillatoria Martini Frémy, O. janthiphora (Fior.-Mazz.) Gomont, O. leatevirens (Grouan) Gomont, $O$. acuminata Gomont, $O$. brevis (Kütz.) Gomont, and O. Boryana Bory ex Gomont, and of Phormidium favosum (Bory) Gomont, Ph. subfuscum Kütz. ex Gomont, Ph. uncinatum Gomont, and Ph: autumnale (Ag.) Gomont, but none of these ten species possesses all the features and measurements of the present one" we hardly feel convinced that these species are new species. For, to discover whether a species is really a new one a thorough study is required not only of the genus concerned but also of the related ones to obtain an understanding of their variability. This must be done both by studying the literature and also by studying a good quantity of material. Now that cultures of Cyanophyceae with hardly any bacterial contamination can be obtained by using ultraviolet radiation, they certainly are very useful to complete such a study of dried specimens and material preserved in liquid, as long as abnormal forms which sometimes appear in cultures are duly recognized.

To make the publication of a new Cyanophycean species valid the nomenclatural type should be dried material and not a mere figure. Dried material of Cyanophyceae can, in most cases, be satisfactorily studied after being soaked in dilute detergent.

Variability in the Cyanophyceae, not only in morphology but also occurring in different circumstances and in different stages of the species has been demonstrated already by CRow $(1923,1924)$ by means of experiments. Yet, he did not go as far as changing the existing concept of the species of the Cyanophyceae with this knowledge. For, in his study of Microcystis (1923) in spite of his statement: "whenever abundant material occurs the precise limits of the different species become impossible to define" and discovering intermediate forms between the species in one and the same environment, he gives a key for 17 species, which he himself judges to be artificial.

Variability in Cyanophyceae was also demonstrated by JAAG's (1945) experiments with a not definitively identified Scytonema. The light intensity appeared not only to influence the colour and the habit of the colony, but also the false branching which could be single, double or wanting, as well as the occurrence of heterocysts which could be more or less abundant or wanting. The number and occurrence of the false branches, as well as the occurrence of the heterocysts are important characters to distinguish genera and families in the Cyanophyceae. A similar result was obtained by STEIN (1963) from her cultures 
of a Tolypothrix species, finding forms with single and forms with double false branches.

In nature, JAAG (1943) discovered the great variability in the sheath and the false branching of Scytonema myochrous, with status crustaceum in extreme dry places, status myochrous in moist habitats and status petalonema in very wet places. Up to that time the three states were considered to be three species: Scytonema crustaceum, Scytonema myochrous and Petalonema alatum, but Jaag discovered intermediate forms. The present author recently collected the same species on a moist east-exposed rock-wall with rare, very short, nearly all single false branches.

Schwabe (1964) in one of his last papers, carefully avoided a definitive delineation of Oscillatoria acutissima Kuff. feeling that a better knowledge of the variability is required.

Unbranched filaments are characteristic for the genus Lyngbya, but in Lyngbya aestuarii occasionally false branching occurs (GOMONT, 1892, p. 149; Koster, 1960, p. 359, fig. 44).

CRow's (1924, p. 407) remark: "The old idea that the naturally occurring forms of Cyanophyceae are numerous polymorphs of a few main types, receives no support from modern systematists" could not be written in these days, since Drouet and DaIly's (1956) and Fan's (1956) revisions of Cyanophycean genera and DroueT's papers on polymorphous Cyanophycean species (1962, 1963, 1964) appeared. For the time being, the changes of more or less well known names of genera and species or placing them into the synonymy of other species, which appeared to be necessary from these revisions, cause certain difficulties and annoyance for many phycologists, such as ecologists, cytologists, physiologists. It is natural that only gradually will the change of names as indicated in the revisions find their way into the phycological papers. Confusing, however, are motiveless alterations of descriptions of species such as in the interesting paper of GIESY (1962, p. 122), where Oscillatoria limosa Agardh is indicated to have trichomes which are 2-6 $\mu$ in diameter. $O$. limosa Ag. ex Gom., a characteristic species, is described by Gomont (1892, p. 211) as having trichomes which are 11-20 (usually 13-16) $\mu$ in diameter.

In extremely variable species it may be of interest to distinguish infraspecific entities, sometimes for convenience' sake rather than of taxonomic value, such as varieties, formae, formae speciales, ecophenes and status indicating minor differences, like in Lyngbya aesturarii (Mertens) Liebm. ex Gom. (Gomont, p. 149, 150) and in Mastigocladus laminosus Cohn ex Kirch. (syn. Hapalosiphon laminosus Hansgirg ex Born. et Flah.) as described by several authors and recently by Anagnostidis (1961, p. 109, p. 279-281).

This paper was written in honour of Dr. J. Lanjouw who has been teaching general plant taxonomy at the Rijksuniversteit of Utrecht for about 35 years. May he find some interest in these remarks about one of the oldest groups of plants, being recorded already from Precambrian, Cambrian, Silurean and Devonian formations. 


\section{REFERENCES}

Anagnostidis, K. 1961. Untersuchungen über die Cyanophyceen einiger Thermen in Griechenland. Thessaloniki. $322 \mathrm{pp}$.

BEck, S. 1963. Licht- und elektronenmikroskopische Untersuchungen an einer sporenbildenden Cyanophycee aus dem Formenkreis von Pleurocapsa fuliginosa Hauck. Flora 153: 194-216.

Cassed, W. A. and W. G. Hutchinson. 1954. Nuclear studies on the smaller Myxophyceae. Exp. Cell. Res. U.S.A. 6 (1): 134-150.

Christensen, T. The gross classification of Algae in D. F. JAGkson, 1964. Algae and Man. New York: 59-64.

Crow, W. B. 1923. Taxonomy and variation of the genus Microcystis in Ceylon. New Phytologist 22: 59-68.

1924. Variation and species in Cyanophyceae. J. of Genetics 14 (3): $397-424$.

Drouet, F. 1962. Gomont's ecophenes of the blue-green alga, Microcoleus vaginatus (Oscillatoriaceze). Proc. Nat. Sci. Philadelphia 114 (6) : 191-205.

1963. Ecophenes of Schizothrix calcicola (Oscillatoriaceae). Proc. Nat. Sci. Philadelphia 115 (9): 261-281.

1964. Ecophenes of Microcoleus chthonoplastes. Rev. Algol. N.S. 7 (4) : 315-324.

and W. A. Daily. 1956. Revision of the coccoid Myxophyceae. Butler Univ. bot. Stud. 12: 1-222.

Echlin, P. and I. MorRIs. 1965. The relationship between blue-green algae and bacteria. Biol. Reviews 40: 143-187.

FAN, K. Ch. 1956. Revision of Calothrix Ag. I. Rev. Algol. N.S. 2 (3): 154-178.

Fotr, B. 1959. Algenkunde. 482 pp. Jena.

FuHs, G. W. 1958. Bau, Verhalten und Bedeutung der kernäquivalenten Strukturen bei Oscillatoria amoena (Kütz.) Gomont. Arch. Mikrobiol. 28 (3): 270-302.

1958. Untersuchungen an Ultradünnschnitten von Oscillatoria amoena (Kütz.) Gomont. Protoplasma 49 (3/4) : 523-540.

Giesy, R. M. 1962. Observations on the cell structure of Oscillatoria limosa Agardh. Ohio J. Sci. 62: 119-125.

Gomont, M. 1892. Monographie des Oscillariacées. Ann. Sci. nat. Bot., Sér. $7,15,16$.

Herbst, F. 1954. Ueber die Kernäquivalente von Aphanothece caldariorum P. Richt. und Pseudanabaena catenata Lauterb. Ber. Deutsch. Bot. Ges. 67 (5) : $183-187$.

1957. Contribution à l'étude cytologique de quelques Cyanophycées. Rev. Algol. N. S. 3 (3): 147-168.

JAAG, O. 1943. Scytonema myochrous (Dillw.) Ag., Formenkreis und Variabilität einer Baualge. Boissiera 7: 437-454.

1945. Experimentelle Untersuchungen über die Variabilität einer Blaualge unter Einfluss verschieden starker Belichtung. Verh. Naturf. Gesellsch. Basel $56(2): 28-40$.

Jensen, T. C. and C. C. Bowen. 1961. Organization of the centroplasm in Nostoc pruniforme. Proc. Iowa Acad. Sci. 68: 86-89.

Jost, M. 1965. Die Ultrastruktur von Oscillatoria rubescens D. C. Arch. f. Mikrobiologie $50(3)$ : 211-245.

KoHz, F. G. 1903. Ueber die Organisation und Physiologie der Cyanophyceenzelle und die mitotische Teilung ihres Kernes. 240 pp. Jena.

Koster, J. TH. 1960. Caribbean brackish and fresh water Cyanophyceae. Blumea 10 (2): 323-366.

Pankow, H. und E. Jahnke. 1964. Lyngbya irregularis nova spec., Oscillatoria lutescens nova spec. und Pseudospirulina amoena nov. gen., nova spec., drei neue hormogonale Blaualgen. Oesterr. Bot. Zeitschr. 111 (4): $331-336$.

und -1965 . Berichtigung. Oesterr. Bot. Zeitschr. $112(1 / 2): 190$.

Pankratz, H. St. and C. C. Bowen. 1963. Cytology of blue-green algae I. The cells of Symploca muscorum. Amer. J. Bot. 50: 387-400. 
RaBinovich, D. 1950. Estudios citológicos sobre la presencia de sustancia nuclear en algunas Schizophyta. Univ. Buenos Aires Contrib. Cient. Ser. bot. 1 (3): 91-157.

Schwade, G. H. 1964. Ueber Oscillatoria acutissima Kuff. Rev. Algol. N.S. 7 (4) : 296-303.

Soriano, S. and R. A. Lewin. 1965. Gliding microbes: some taxonomic reconsiderations. Antonie van Leeuwenhoek 31: 66-80.

Stern, J. R. 1963. Morphological variation of a Tolypothrix in culture. Brit. Phyc. Bull. 2 (4): 206-210.

Sus, C. N. 1961. Electron microscope observations on Gloeocapsa sp. Bull. Torrey Bot. Club 88 (2): 106-110.

Welsh, H. 1964. A new species of Oscillatoria Bory. Revue Algol. N.S. 7 (3): 256-259. 